\title{
The effects of age and sex steroids on the macrophage population in the ovary of the chicken, Gallus domesticus
}

\author{
A. Barua ${ }^{1}$, Y. Yoshimura ${ }^{1 *}$ and T. Tamura ${ }^{2}$ \\ ${ }^{1}$ Graduate School for International Development and Cooperation and \\ ${ }^{2}$ Faculty of Applied Biological Science, Hiroshima University, Higashi-Hiroshima 739-8529, Japan
}

\begin{abstract}
The role of macrophages in the function of the hen ovary has not yet been described, although these cells may be an important regulator of ovarian function in mammals. The aim of this study was to determine the changes in the frequency of macrophages during ageing and follicular atresia, and the effects of sex steroids on the macrophage population in the hen ovary. Cryostat sections of ovarian tissues of immature, young laying and old laying hens and those of immature hens treated with or without diethylstilboestrol (DES) or progesterone were immunostained for macrophage cells using mouse anti-chicken macrophage monoclonal antibody. Macrophages were observed under a light microscope and counted using a computer assisted image analyser. The frequency of macrophages in both the stroma and theca of primary follicles was significantly greater in young laying hens than in immature and old laying hens and these cells were more frequent in old laying hens than in immature hens $(P<0.01)$. Macrophages were more frequent in atretic follicles than in normal follicles $(P<0.01)$. The number of macrophages in both the stroma and theca of primary follicles of DES-treated birds was significantly greater than in those of progesterone-treated and control birds $(P<0.01)$. Progesterone had no significant effect on the population of macrophages. These results suggest that macrophages in the ovary increase in association with sexual maturation of birds and atresia of follicles and decrease during ageing. Oestrogen may be one of the factors that affect the population of macrophages in the hen ovary.
\end{abstract}

\section{Introduction}

Macrophages exert a broad range of immunological functions such as phagocytosis of pathogens, antigen presentation and cytokine production in birds (Qureshi $e t$ al., 1994) as well as in mammals (Powell, 1987). Ovarian macrophages are pivotal regulators of follicular development (Fukumatsu et al., 1992, 1995), steroidogenesis (Petrovska et al., 1996), ovulation (Brannstrom and Norman, 1993) and regression of the corpus luteum (Anderson $\mathrm{et}$ al., 1996) in several mammalian species. Macrophages also play a role in removing the follicular cells undergoing atresia in rabbits (Kasuya, 1995) and in mice (Hume et al., 1984; Petrovska ct al., 1996). Tumour necrosis factor $\alpha$ (TNF- $\alpha$ ), an important product of macrophages, increases ovulation rate (Takehara et al., 1994; Araki et al., 1996), and follicular atresia (Stern and Coulam, 1992; Hsueh et al., 1994) in mammals and also stimulates ovarian progesterone and androgen production (Kirsch et al., 1981; Roby and Terranova, 1988; Adashi, 1990; Roby et al., 1990). Interleukin 1 (IL-1), another macrophage product, mediates the induction of ovulation by

${ }^{*}$ Correspondence.

Revised manuscript received 14 April 1998 gonadotrophins and suppresses immature follicular luteinization in mammals (Gotschall et al., 1988).

Chicken macrophages exert many functions similar to mammalian macrophages (Qureshi et al., 1993) and may therefore play an important role in ovarian events in hens, such as follicular growth, atresia and ovulation. Previous studies have suggested that chicken ovarian tissues are targets for sex steroids because receptors for progesterone (Yoshimura and Bahr, 1991), androgen (Yoshimura et al., 1993a) and oestrogen (Yoshimura et al., 1995) are localized in the ovary. In addition, progesterone (Yoshimura et al., 1993b) and oestrogen (Yoshimura and Tamura, 1986) suppress the induction of follicular atresia in hypophysectomized hens. Bahr and Palmer (1989) reported that oestrogen production decreases during ageing in hens.

Immune functions decline with ageing (Tada, 1992) and oestradiol enhances macrophage activity in mammals (Vernon-Roberts, 1969). Therefore, ageing and sex steroids may affect the frequency of immunocompetent cells, including macrophages, in the ovary. To date, there are no reports on the localization of macrophages in the hen ovary and the factors that regulate their migration. The aim of this study was to determine the localization of macrophages in the ovary of hens and how this localization is affected by age and sex steroids. 


\section{Materials and Methods}

\section{Birds}

Immature and mature White Leghorn hens were kept in individual cages under a light regimen of $14 \mathrm{~h}$ light: $10 \mathrm{~h}$ dark, and were provided with feed and water ad libitum. The birds were divided into three groups ( $n=5$ birds each) for the experiment to examine the effects of sexual maturation and ageing on the frequency of macrophages in the ovary: immature birds (approximately 50 days old); young laying hens (approximately 180 days old and laying five or more eggs in a sequence); and old laying hens (approximately 450 days old and laying two or three eggs in a sequence). In the experiment to examine the effects of sex steroids on the frequency of macrophages in the ovary, immature birds ( 30 days of age) were divided into three groups ( $n=5$ birds each) that were treated with or without sex steroids, namely sesame oil (vehicle)-, DES- and progesterone-treated groups. DES (Nacalai Tesque, Kyoto) and progesterone (Sigma, St Louis, MO) were dissolved in sesame oil (Nacalai Tesque, Kyoto) at a concentration of $10 \mathrm{mg} \mathrm{ml}^{-1}$ before injection. Immature birds were injected i.m. once a day with DES (1 mg per bird), progesterone ( $1 \mathrm{mg}$ per bird) or vehicle $(0.1 \mathrm{ml}$ per bird) for 7 days.

\section{Tissue preparation}

The immature and mature hens were killed by decapitation and the ovarian stromal tissues were collected. All tissues were embedded in OCT compound (Miles Inc., Elkhart, IN) and snap-frozen in a mixture of isopentane and solid carbon dioxide. Cryostat sections of the tissues $(15 \mu \mathrm{m}$ in thickness) were air dried on slides treated with 3aminopropyl-triethoxysilane (Nacalai Tesque, Kyoto) as described by Van Prooijen-Knegt et al. (1982). The sections were then fixed for $10 \mathrm{~min}$ with cold acetone and methanol.

\section{Antibodies}

Mouse monoclonal anti-chicken macrophage antibody, K1 (Kaspers et al., 1993), kindly provided by Dr Lillehoj, USDA, USA, was used for the primary antibody. K1 antibody recognizes macrophages and thrombocytes (Kaspers et al., 1993). Macrophages are non-uniform in shape and are located in various tissues (Qureshi et al., 1994), whereas thrombocytes are oval in shape and are located only in the blood vessels (Swenson, 1984). In this study, there were very few thrombocytes that were positive for $\mathrm{K} 1$ in the blood vessels and these were omitted from the investigation. Only macrophages in the ovarian tissues were observed. An immunodetection kit S-HRP (Seikagakukogyo Co., Tokyo) was used for the detection of immunoprecipitates of primary antibody.

\section{Immunostaining}

The sections were washed with PBS for $15 \mathrm{~min}(3 \times 5 \mathrm{~min})$ and incubated with $1 \%$ goat serum for 15 min to block the non-specific bindings of antibodies. The sections were then incubated overnight with mouse anti-chicken macrophage antibody diluted with PBS containing $0.5 \%(w / v)$ BSA at a concentration of 1:20, followed by washing with PBS for 15 $\min (3 \times 5 \mathrm{~min})$. Immunoreactions of the first antibody on the sections were detected using an S-HRP immunostaining kit according to the manufacturer's instructions. Briefly, the sections were incubated with the biotinylated secondary antibody and with avidin-biotin-peroxidase complex for $1 \mathrm{~h}$. Finally, immunoprecipitates were visualized by incubating with a mixture of $0.02 \%(\mathrm{w} / \mathrm{v}) \quad 3^{\prime}, 3^{\prime}$-diaminobenzidine tetrahydrochloride (Sigma, St Louis, $\mathrm{MO}$ ) and $0.001 \% \mathrm{H}_{2} \mathrm{O}_{2}$ in 0.05 mol Tris-HCl $~^{-1}$ ( $\mathrm{pH} \mathrm{7.6).} \mathrm{After} \mathrm{immunostaining,}$ the sections were counterstained with haematoxylin, dehydrated and covered. Control staining was carried out simultaneously in which the first antibody was replaced with normal mouse IgG. No positive staining was found in the control slides. Sections were observed under a light microscope or a phase-contrast microscope.

\section{Counting of macrophages}

The sections were examined under a light microscope using software for image analysis (Mac Aspect, Mitani Co., Fukui). The number of macrophages identified by $\mathrm{K} 1$ was obtained by observing three different regions in each theca (approximately $0.5-30 \times 10^{4} \mu \mathrm{m}^{2}$ tissue) and stroma (approximately $3-6 \times 10^{4} \mu \mathrm{m}^{2}$ tissue). The number of cells in $1 \times 10^{4} \mu \mathrm{m}^{2}$ tissue was then calculated. The average of the three counts was expressed as the number of cells in $1 \times 10^{4} \mu \mathrm{m}^{2}$ in one tissue of a bird.

\section{Statistical analysis}

The significance of differences in the number of positive cells was determined by one-way analysis of variance followed by Duncan's multiple range test.

\section{Results}

\section{Effects of ageing on the frequency of macrophages}

The ovarian stroma consisted of loose connective tissue containing primary follicles. Macrophages were localized in the ovarian stroma and theca of normal primary follicles in all birds examined (Fig. 1). The frequency of macrophages in the stroma and theca of primary follicles of immature birds was approximately 1.5 cells and 1.2 cells in $1 \times 10^{4} \mu \mathrm{m}^{2}$ tissue, respectively. The frequency of macrophages was significantly higher in the stroma and theca of primary follicles of young laying and old laying hens compared with immature hens $(P<0.01)$ (Fig. 2$)$. In addition, the frequency was significantly greater in young laying hens than in old laying hens $(P<0.01)$.

\section{Frequency of macrophages in normal and atretic follicles}

The early stages of atresia in the primary follicles were identified by the disruption of the oocyte with loosening of 

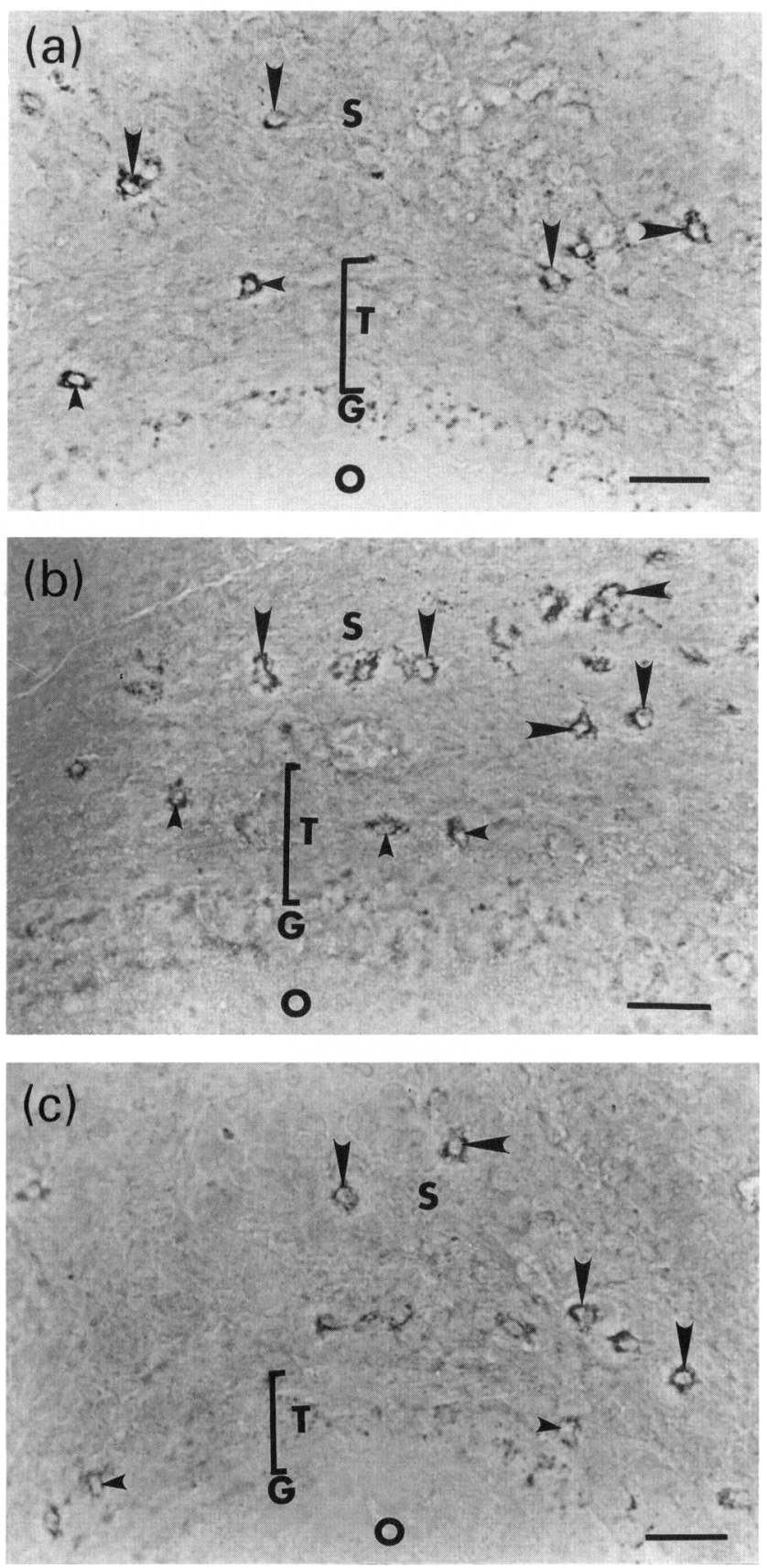

Fig. 1. Phase-contrast micrographs of chicken ovarian sections immunostained for macrophage cells. (a) Ovarian stroma of normal immature hen. A few macrophages are observed in the stroma and theca of the primary follicles. (b) Ovarian stroma of young laying hen. Many macrophages are observed in the stroma and theca of the normal primary follicles. (c) Ovarian stroma of old laying hen. Macrophages are observed in both the stroma and the theca of the normal primary follicles, although there are fewer in number compared with young laying hens. Large arrowheads indicate examples of macrophages in the stroma and small arrowheads indicate examples of macrophages in the theca. $G$, granulosa layer; O, oocyte; S, stroma; $T$, thecal layer. Scale bars represent $20 \mu \mathrm{m}$.

granulosa cell adhesion (Fig. 3a). The late stages of atresia were identified by the invasion of the follicular cavity by granulosa cells that detached from the thecal layer (Fig. 3b).

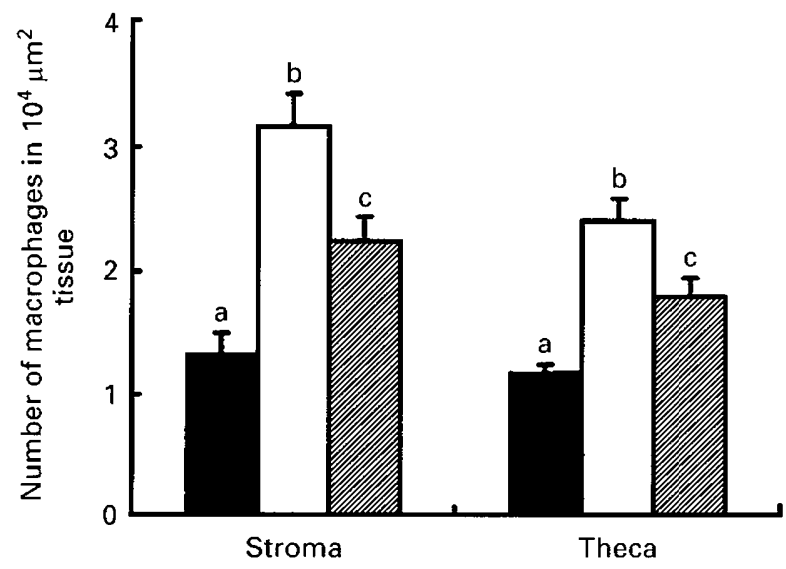

Fig. 2. Frequency of macrophages in the ovarian stroma and thecal layer of normal primary follicles of $(\boldsymbol{\square})$ non-treated immature hens $(\square)$, young laying hens and $(\mathbb{Z})$ old laying hens. Each value shows mean \pm SEM of the macrophages in $1 \times 10^{4} \mu \mathrm{m}^{2}$ tissue $(n=5$ birds each). Bars with different letters are significantly different $(P<0.01)$.

Macrophages were localized in the theca and among granulosa cells within the follicular cavity of both types of atretic follicles (Fig. 3a,b). The population of macrophages in the thecal layer was $1.2 \pm 0.2$ cells $(n=5)$ in $1 \times 10^{4} \mu \mathrm{m}^{2}$ tissue in normal primary follicles and increased significantly $(P<0.01)$ to $15.0 \pm 1.7$ cells $(n=5)$ in $1 \times 10^{4} \mu \mathrm{m}^{2}$ tissue in primary follicles in the early stages of atresia. A markedly increased population of macrophages was also observed in the theca and follicular cavity in the late stages of atresia.

\section{Effects of sex steroids on the frequency of macrophages}

There was no significant histological difference in the ovarian structures among DES-, progesterone- and oiltreated (control) immature birds (Fig. 4a-c). In the stroma of control birds, macrophages were observed at a frequency of approximately 1.4 cells in $1 \times 10^{4} \mu \mathrm{m}^{2}$ tissue and the frequency increased approximately four-fold in DES-treated birds $(P<0.01)$ (Fig. 5). In the thecal layer of primary follicles of DES-treated birds, the frequency of macrophages was approximately four cells in $1 \times 10^{4} \mu \mathrm{m}^{2}$ tissue which is approximately three times higher compared with control birds $(P<0.01)$. Progesterone showed no significant effect on the frequency of macrophage in the ovarian stroma and theca of primary follicles compared with control birds.

\section{Discussion}

The main findings of this study were: (i) the frequency of macrophages in the ovarian stroma and theca of normal primary follicles significantly increases as birds reach sexual maturity and thereafter decreases during ageing; (ii) the frequency of macrophages is higher in atretic follicles than in normal follicles; and (iii) the frequency of macrophages significantly increases in the ovary of DES-treated immature hens but not in progesterone-treated birds.

The population of macrophages increased significantly in 

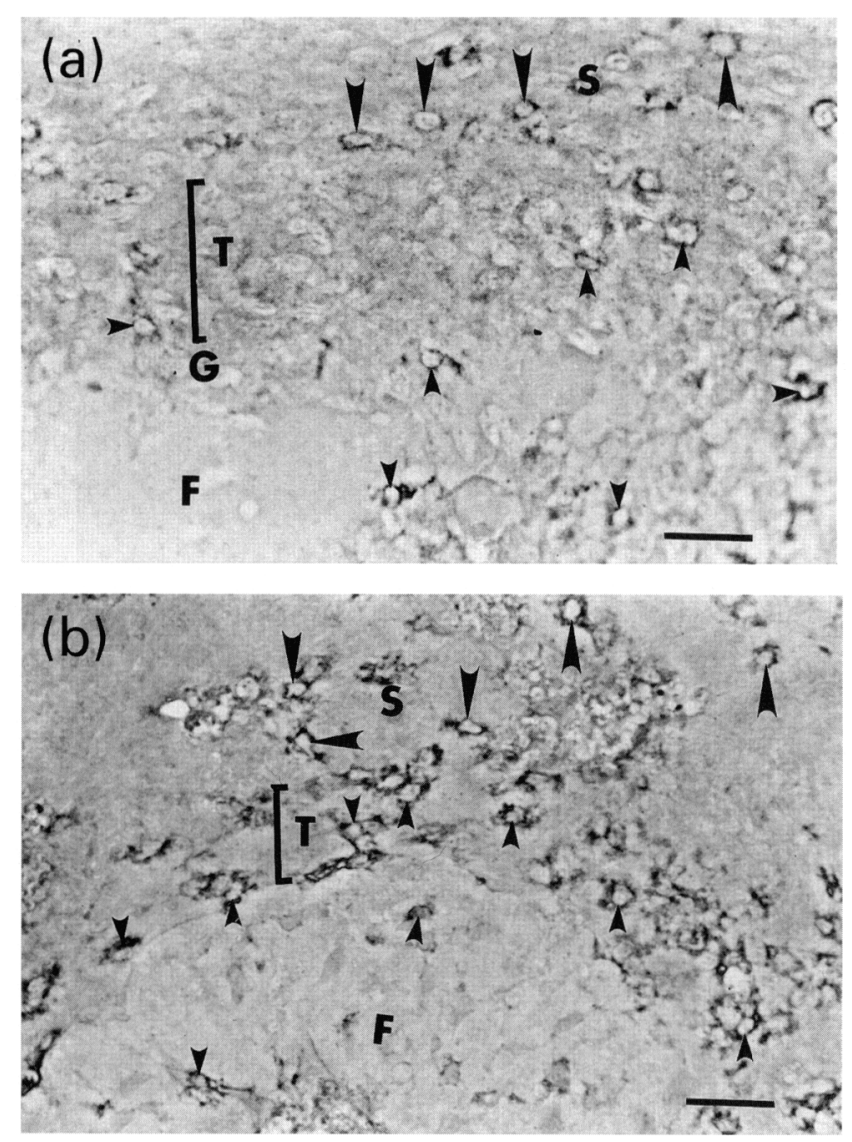

Fig. 3. Phase-contrast micrographs of sections of atretic follicles of laying hens immunostained for macrophages. (a) Primary follicles at an early stage of atresia. Some granulosa cells are detached from the thecal layer. Many macrophages are observed in the theca as well as in the area in which the granulosa cells are detached. (b) Primary follicles at a late stage of atresia. The thecal layer is markedly disintegrated and the granulosa cells have invaded the follicular cavity. Numerous macrophages are observed in the theca and granulosa layers, the follicular cavity and the stroma surrounding the follicle. Large arrowheads indicate examples of macrophages in the stroma and small arrowheads indicate examples of macrophages in the follicular cavity and the theca and granulosa layers. F, follicular cavity; G, granulosa layer; $S$, stroma; $T$, thecal layer. Scale bars represent $20 \mu \mathrm{m}$.

the ovary of young laying hens compared with immature hens and decreased significantly in old laying hens. This suggests that the number of macrophages increases when a bird reaches sexual maturity and decreases during ageing. This age-dependent change in the frequency of macrophages may be associated with ovarian functions such as folliculogenesis and steroidogenesis. Bahr and Palmer (1989) found that aromatase activity and the reduction in the number of small follicles were responsible for oestrogen production during ageing in chickens. In this study, injection of immature hens with DES but not progesterone increased the population of macrophages in the ovarian stroma and the theca of primary follicles in immature hens. Therefore, the higher frequency of macrophages in the ovary of young laying hens compared with immature and old laying hens may be associated with the presence of a greater number of
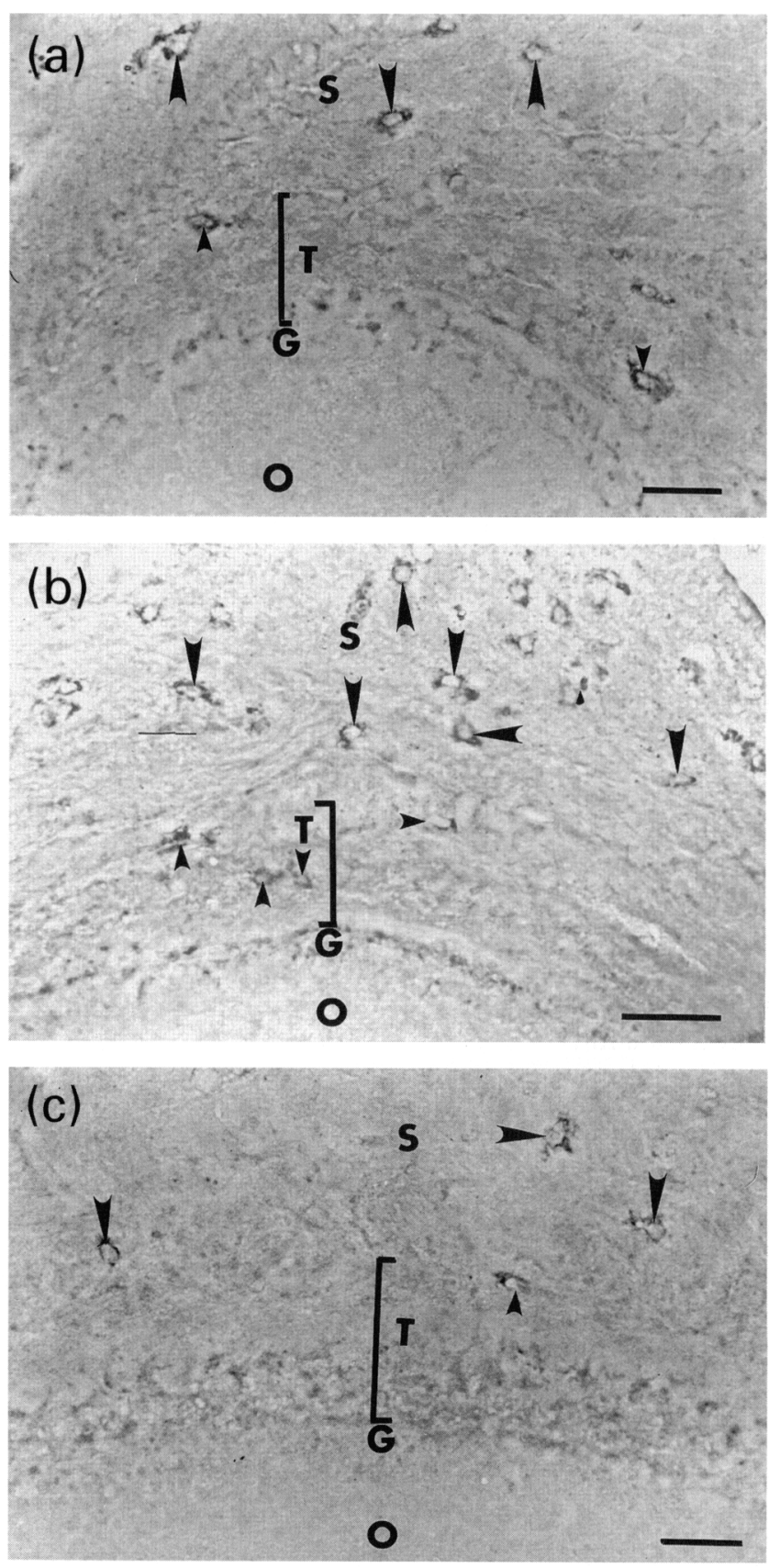

Fig. 4. Phase-contrast micrographs of ovarian sections of immature hens treated with or without sex steroids and immunostained for macrophages. (a) Ovarian stroma of immature hen treated with oil (vehicle). A few macrophages are observed in the ovarian stroma and theca of the normal primary follicles. (b) Ovarian stroma of diethylstilboestrol (DES)-treated immature hen. Many macrophages are observed in the stroma and theca of the normal primary follicles. (c) Ovarian stroma of progesterone-treated immature hen. There are a few macrophages in both the stroma and theca of the normal primary follicles. Arrowheads indicate examples of macrophages. $G$, granulosa layer; $\mathrm{O}$, oocyte; $\mathrm{S}$, stroma; $\mathrm{T}$, thecal layer. Scale bars represent $20 \mu \mathrm{m}$.

growing follicles and increased oestrogen production. The higher frequency of macrophages in young laying hens may contribute to more active tissue turnover after ovulation.

The presence of receptors for oestrogen (Yoshimura et al., 


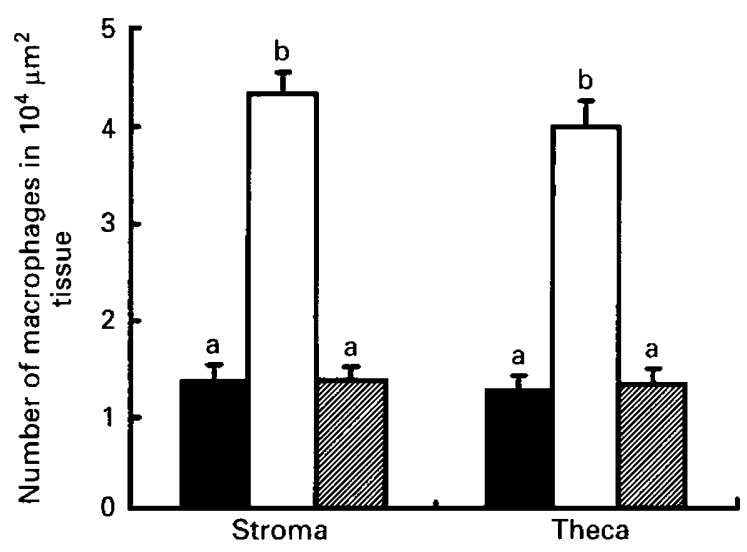

Fig. 5. Frequency of macrophages in the ovarian stroma and thecal layer of normal primary follicles of immature hens treated with (ם)

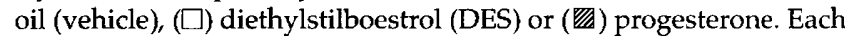
value shows mean \pm SEM of the macrophages in $1 \times 10^{4} \mu \mathrm{m}^{2}$ tissue $(n$ $=5$ birds each). Bars with different letters are significantly different $(P<0.01)$.

1995), androgen (Yoshimura et al., 1993a) and progesterone (Yoshimura and Bahr, 1991) in the ovary of chickens indicates that ovarian tissues are target sites for sex steroids. There are reports that immunity is enhanced by oestrogen and is suppressed by progesterone in birds (Cheville, 1978) and in mammals (Pate, 1995). The results of the present study suggest that oestrogen may be one of the factors that promotes infiltration of the chicken ovary by macrophages because injection of immature hens with DES increased the frequency of macrophages in the ovary. There are several mechanisms by which oestrogen may increase the ovarian population of macrophages. First, oestrogen may stimulate the turnover of ovarian tissue, causing the infiltration of macrophages to phagocytose the degraded tissues. Second, oestrogen may stimulate the production of macrophage chemotactic factors by ovarian tissues. Qureshi et al. (1993) reported that in chickens the migration of macrophages into various tissues was induced by chemotactic factors. Shao $e t$ al. (1996) reported the presence of a macrophage colony stimulating factor in the egg yolk of chickens. In mammals, oestrogen increases the synthesis of macrophage colony stimulating factor and granulocyte macrophage colony stimulating factor, which regulate infiltration of the ovary and oviduct by macrophages, and progesterone inhibits the synthesis of these factors (Araki et al., 1996; Robertson et al., 1996).

Macrophages were localized in the theca but not in the granulosa layer of normal primary follicles. In contrast, in atretic primary follicles, macrophages were localized in the granulosa layer and in the follicular cavity as well as in the thecal layer at a greater frequency than in normal follicles. Increased numbers of macrophages were also found in the atretic follicles of mice (Simon et al., 1994), rats (Bukovsky et al., 1983) and rabbits (Kasuya, 1995). Apoptosis has been described as the underlying mechanism of follicular atresia in chickens (Witty et al., 1996) as well as in mammals (Stern and Coulam, 1992). TNF- $\alpha$ secreted by macrophages is involved in the apoptotic process of follicular atresia in mammals (Hsueh et al., 1994). In addition, it is thought that macrophages phagocytose the debris of apoptotic cells (Bowen and Bowen, 1990). The localized increase of macrophages in atretic follicles in hens may be involved in the phagocytic removal of atretic follicular tissues. It is not known whether macrophages are involved in the induction of atresia because atretic follicles are more frequent in old laying hens than in young laying hens (Bahr and Palmer, 1989). However, there were fewer macrophages in the ovary of old laying hens compared with young laying hens in the present study. It is likely that the factors that induce macrophages to infiltrate atretic follicles are not regulated by oestrogen, because oestrogen production in these follicles is lower than in normal small follicles (Bahr and Palmer, 1989). Further studies are required to determine the factors that promote macrophages to infiltrate atretic follicles.

In conclusion, the number of macrophages increases in the hen ovary during sexual maturation and decreases during ageing. It is likely that oestrogen is one of the factors that induces macrophages to infiltrate the ovary, although the precise mechanism for this remains to be studied.

The authors wish to thank H. Lillehoj, USDA, for providing the monoclonal antibody to chicken macrophages, K1.

\section{References}

Adashi EY (1990) The potential relevance of cytokines to ovarian physiology: the emerging role of resident ovarian cells of the white blood cell series Endocrine Reviews 11 454-464

Anderson LA, Webb R, Kindahl M, Brambley TA and Watson ED (1996) Immune cell populations in the bovine corpus luteum following inhibition of prostaglandin $F_{2 \alpha}$ production between days 16 and 18 of the oestrous cycle Journal of Reproduction and Fertility Abstract Series $\mathbf{1 7}$ p. 35

Araki M, Fukumatsu Y, Katabuchi H, Shultz LD, Takahashi K and Okamura H (1996) Follicular development and ovulation in macrophage colonystimulating factor-deficient mice homozygous for the osteoperosis (op) mutation Biology of Reproduction 54 478-484

Bahr JM and Palmer SS (1989) The influence of ageing on ovarian function Critical Reviews in Poultry Biology 2 103-110

Bowen ID and Bowen SM (1990) Programmed cell death. In Programmed Cell Death in Tumours and Tissues pp 26-50 Eds ID Bowen and SM Bowen. University Press, Cambridge and London

Brannstrom M and Norman RJ (1993) Involvement of leukocytes and cytokines in the ovulatory process and corpus luteum function Human Reproduction 8 1762-1775

Bukovsky A, Presl J, Zyidovsky J and Mancal P (1983) The localization of Thy-1.1, MRC $O \times 2$ and Ia antigens in the rat ovary and fallopian tube Immunology 48 587-596

Cheville NF (1978) Environmental factors affecting the immune response of birds Avian Diseases 23 308-314

Fukumatsu Y, Katabuchi H, Naito M, Takeya M, Takahashi K and Okamura $\mathbf{H}$ (1992) Effect of macrophages on proliferation of granulosa cells in the ovary in rats Journal of Reproduction and Fertility 96 241-249

Fukumatsu Y, Katabuchi $\mathbf{H}$ and Okamura $\mathbf{H}$ (1995) Immunohistochemical localization of epidermal growth factor and its effect on granulosa cell proliferation in rat ovary Journai of Endocrinology $42467-473$

Gottschall PE, Katsuura G, Hoffman ST and Arimura A (1988) Interleukin-1: an inhibitor of luteinizing hormone receptor formation in cultured rat granulosa cells FASEB Journal 2 2492-2496

Hsueh AJW, Biling $\mathbf{H}$ and Tsafriri A (1994) Ovarian follicle atresia: a hormonally controlled apoptotic process Endocrine Reviews 15 707-724

Hume DA, Halpin D, Charlton H and Gordon S (1984) The mononuclear phagocyte system of the mouse defined by immunohistochemical localization of antigen F4/80: macrophages of endocrine organs Proceedings of National Academy of Sciences USA 81 4174-4177

Kaspers B, Lillehoj HS and Lillehoj EP (1993) Chicken macrophages and 
thrombocytes share a common cell surface antigen defined by a monoclonal antibody Veterinary Immunology and Immunopathology 36 333-346

Kasuya K (1995) The process of apoptosis in follicular epithelial cells in the rabbit ovary with special reference to the involvement of macrophages Archives of Histology and Cytology 58 257-264

Kirsch TM, Friedman AC, Vogel RL and Flickinger GL (1981) Macrophages in the corpora lutea of mice: characterization and effect on steroid secretion Biology of Reproduction 25 629-638

Pate JL (1995) Involvement of immune cells in regulation of ovarian functions Journal of Reproduction and Fertility Supplement 49 365-377

Powell PC (1987) Macrophages and other nonlymphoid cells contributing to immunity. In Avian Immunology: Basis and Practice pp 195-212 Eds A Toivanen and P Toivanen. CRC Press Inc., Boca Raton, FL

Petrovska M, Dimitrov DG and Michael SD (1996) Quantitative changes in macrophage distribution in normal mouse ovary over the course of oestrous cycle examined with an image analysis system American Journal of Reproductive Immunology 36 175-183

Qureshi MA, Petitte JN, Laster SM and Dietert RR (1993) Avian macrophages: contribution to cellular microenvironment and changes in effector functions following activation Poultry Science 72 1280-1284

Qureshi MA, Marsh JA, Dietert RR, Sung Y-J, Nicolas-Bolnet C and Petitte JN (1994) Profiles of chicken macrophage effector function Poultry Science 73 1027-1034

Robertson SA, Mayrhofer G and Seamark RF (1996) Ovarian steroid hormones regulate macrophage-colony-stimulating factor synthesis by uterine epithelial cells in the mouse Biology of Reproduction 54 183-196

Roby KF and Terranova PF (1988) Tumor necrosis factor- $\alpha$ alters follicular steroidogenesis in vitro. Endocrinology 123 2952-2954

Roby KF, Weed J, Lyles R and Terranova PF (1990) Immunological evidence for a human ovarian tumor necrosis factor-alpha Journal of Clinical Endocrinology and Metabolism 71 1096-1102

Shao X, Kikuchi K, Watari E, Norose Y, Araki T and Yokomuro K (1996) Changes in M-CSF activity during chicken embryonic development Reproduction Fertility and Development 8 103-109
Simon C, Frances A, Piquette G and Polan ML (1994) Immunohistochemical localization of the interleukin-1 system in the mouse ovary during follicular growth, ovulation and luteinization Biology of Reproduction 50 449-457

Stern J and Coulam CB (1992) New concepts in ovarian regulation: an immune insight American Journal of Reproductive Immunology 27 136-144

Swenson MJ (1984) Physiological properties and cellular and chemical constituents of blood. In Duke's Physiology of Domestic Animals 10th Edn pp 15-40 Ed. MJ Swenson. Cornell University Press, London

Takehara Y, Dharmarajan AM, Kaufman G and Wallach EE (1994) Effect of interleukin- $1 \alpha$ on ovulation in the in vitro purfused rabbit ovary Endocrinology 134 1788-1792

Tada T (1992) Nutrition and the immune system: an overview Nutrition Reviews $\mathbf{5 0} 360$

Vernon-Roberts B (1969) The effect of steroid hormones on macrophage activity International Review of Cytology 25 131-142

Van Prooijen-Knegt AC, Raaf AK, Van Der Burge MJ, Vrolijk J and Van Der Ploeg M (1982) Spreading and staining of human metaphase chromosomes on aminoalkyl-silane-treated glass slides Histochemical Journal 14 333-344

Witty JP, Bridgham JT and Johnson AL (1996) Induction of apoptotic cell death in hen granulosa cells by ceramide Endocrinology 137 5269-5277

Yoshimura Y and Bahr JM (1991) Localization of progesterone receptors in pre- and postovulatory follicles of domestic hen Endocrinology 128 323-330

Yoshimura $Y$ and Tamura T (1986) Effects of oestradiol administration on the follicular tissue of hypophysectomized hens Poultry Science 65 1808-1810

Yoshimura Y, Chang C, Okamoto T and Tamura T (1993a) Immunolocalization of androgen receptor in the small, preovulatory and postovulatory follicles of laying hens General and Comparative Endocrinology 91 81-89

Yoshimura Y, Bahr JM, Okamoto T and Tamura T (1993b) Effect of progesterone on the ultra structure of preovulatory follicles of hypophysectomized chickens: possible role of progesterone in the regulation of follicular function Japanese Poultry Science 30 270-281

Yoshimura Y, Okamoto $T$ and Tamura $T$ (1995) Changes in localization of ovarian immunoreactive oestrogen receptor during follicular development in hens General and Comparative Endocrinology 100 1-7 